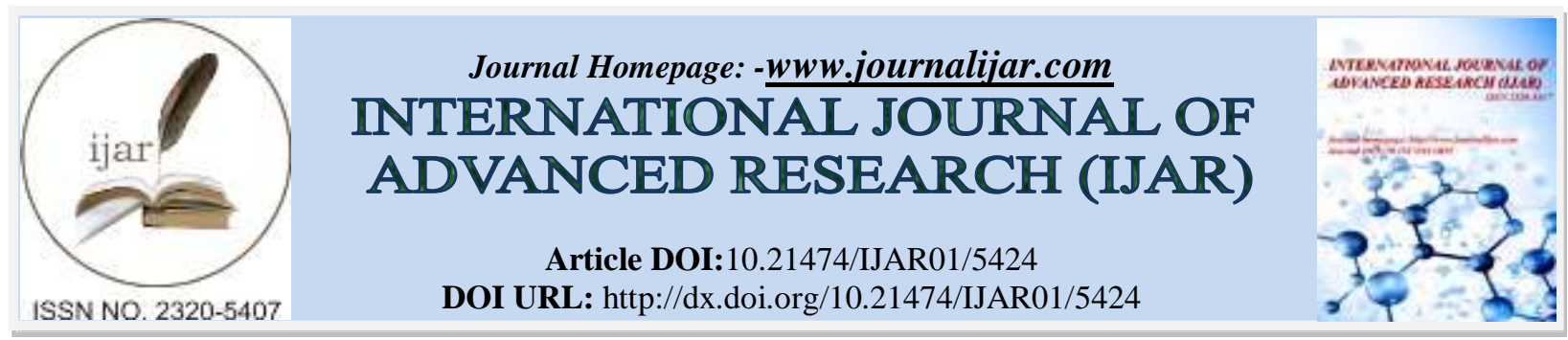

RESEARCH ARTICLE

\title{
OPTIMIZATION OF FERMENTATION CONDITIONS FOR THE ETHANOL PRODUCTION FROM SUGARCANE BAGASSE BY ZYMOMONAS MOBILIS USING RESPONSE SURFACE METHODOLOGY.
}

\section{*Danielle da Silveira dos Santos Martins ${ }^{1}$, Aghata Rodrigues Souza ${ }^{2}$, Elcio R. Borges ${ }^{2}$, Jessica D. Peña ${ }^{2}$ and} Nei Pereira $\mathbf{J r}^{2}$.

1. NUPEM, Nucleus in Ecology and Socio-environmental Development of Macaé- Federal University of Rio de Janeiro.

2. Laboratories of Bioprocess Development, Center of Technology - School of Chemistry, Federal University of Rio de Janeiro.

\section{Manuscript Info}

\section{Manuscript History}

Received: 14 July 2017

Final Accepted: 16 August 2017

Published: September 2017

Key words:-

Sugarcane bagasse, Optimization, Bioethanol, SSF, Z.mobilis.

\begin{abstract}
The use of biomass as renewable sources of energy has increased industrial focus toward alternative fuel because of the depletion of fossil fuel reserves, the unstable panorama of the petrol prices, the increasing environmental and political pressures. The new concept of bioethanol corresponds to its production using raw cellulosic materials, such as sugarcane bagasse. The bacterium Zymomonas mobilis was shown to be extremely attractive for the ethanol second generation production from glucose of the cellulosic fraction, due to its high capacity to absorb this sugar, resulting in high ethanol productivity values. The aim of this work was to study the influence between the medium components: Yeast Extract, $\mathrm{KH}_{2} \mathrm{PO}_{4},\left(\mathrm{NH}_{4}\right)_{2} \mathrm{SO}_{4}, \mathrm{MgSO}_{4} \cdot 7 \mathrm{H}_{2} \mathrm{O}$ to optimize the fermentation conditions for the ethanol production from sugarcane bagasse by $Z$. mobilis. Initially, to make easier the accessibility of cellulases to the cellulose microfibrils, the bagasse was submitted to a pretreatment with diluted acid to fractionate and extract the hemicellulose component from the solid residue named cellulignin and then, this solid residue was pretreated using $\mathrm{NaOH}(4 \%)$ aiming at its partial delignification. Thereafter, the pretreated cellulignin underwent the action of a commercial cellulolytic preparation, allowing the conversion from cellulose to glucose. This enzymatic pretreatment occurred under temperature of $50^{\circ} \mathrm{C}$ for 12 hours, after which the temperature reduced to $30^{\circ} \mathrm{C}$ and we inoculated the system with cells of Z. mobilis. It has been used statistical experimental design to optimize the conditions of SSF, evaluating the medium components. The optimum conditions found were $12.5 \mathrm{~g} / \mathrm{L}$ of Yeast Extract, $2.5 \mathrm{~g} / \mathrm{L}$ of $\mathrm{KH}_{2} \mathrm{PO}_{4} ; 1.5 \mathrm{~g} / \mathrm{L}$ of $\left(\mathrm{NH}_{4}\right)_{2} \mathrm{SO}_{4} ; 1.5 \mathrm{~g} / \mathrm{L}$ of $\mathrm{MgSO}_{4} .7 \mathrm{H}_{2} 0$, respectively; achieving $65.3 \mathrm{~g} / \mathrm{L}$ of ethanol.
\end{abstract}

Copy Right, IJAR, 2017,. All rights reserved.

\section{Introduction:-}

For the future, completely new approaches in research and development a re-arrangement of a sustainable economy to biological raw materials, production, and economy are necessary (1). The new concept of bioethanol corresponds 
to its production from conventional raw materials such as sugarcane, beet or starch, due to their low-cost, availability and renewability. The use of biofuels can contribute to the mitigation of GHG emissions, provide a clean and therefore sustainable energy source, and increase the agricultural income for rural poor in developing countries (2). Developing countries have a comparative advantage for biofuel production because of greater availability of land, favorable climatic conditions for agriculture and lower labour costs. However, there may be other socioeconomic and environmental implications affecting the potential for developing countries to benefit from the increased global demand for biofuel (3).

Ethanol production technology based on lignocellulosic biomass uses chemical and enzymatic processes for the hydrolysis of cellulose, which produces carbohydrates (sugars) and then fermented into ethanol (4). Bioethanol is by far the most widely used biofuel for transportation worldwide. Bioethanol and bioethanol/gasoline blends have a long history as alternative transportation fuels. Germany and France have used it as early as 1894 by the then incipient industry of internal combustion engines (ICEs) (5). Brazil has utilized bioethanol as a fuel since 1925. By that time, the production of bioethanol was 70 times bigger than the production and consumption of petrol (6).

The largest ethanol producing countries are USA and Brazil, responsible for the production of $54 \times 10^{6}$ and $21 \times 10^{6} \mathrm{~m}^{3}$ in 2011, respectively (7). Brazil utilizes sugarcane for bioethanol production while the United States and Europe mainly use starch from corn, and from wheat and barley, respectively. Sugarcane as a biofuel crop has much expanded in the last decade, yielding anhydrous bioethanol (gasoline additive) and hydrated bioethanol by fermentation and distillation of sugarcane juice and molasses (8). Brazil's estimative of sugarcane yield production averages about $617 \times 10^{6}$ tons in 2017 (9). Brazil is the largest single producer of sugarcane with about $31 \%$ of global production (10). It has nearly 9 million hectares of sugarcane under cultivation. Sugar beet crops grow in most of the EU-25 countries, and yield substantially more bioethanol per hectare than wheat.

The acid pretreatment causes the hydrolysis of hemicellulose under conditions of low-grade severity (acid concentration, temperature, time of exposure and solid: liquid relationship). After pretreatment step, two fractions are generated: a liquid containing the hemicellulose hydrolyzed and a solid called cellulignin. This solid waste needs alkaline treatment aimed at the partial removal of lignin through the structural separation of the connections between the phenolic macromolecule and cellulose, increasing thus the accessibility of enzymes to cellulose fibers. The raw materials of lignocellulosic origin contain $20 \%$ to $60 \%$ of cellulose that convert into glucose by enzymatic action. Glucose is a monosaccharide used by all major microorganisms, making it an important building block to obtain substances that ranging from fuels to polymers (11).

The research on ethanol have been targeted for the process of Saccharification and Simultaneous Fermentation (SSF), which combines in one-step enzymatic hydrolysis and fermentation of glucose coming from the cellulose hydrolysis (12). This strategy is justified because the hydrolysis products (glucose and cellobiose) inhibit the cellulase complex enzymes. The SSF process of waste materials provides the use of available low-cost substrates. These processes have been employed in various pilot plants. Moreover, the SSF process permits high productivity of ethanol, using fewer amounts of enzymes (13), when compared to those processes utilizing separated enzymatic hydrolysis and fermentation.

The most frequently used microorganism for fermenting bioethanol in industrial processes is $S$. cerevisiae, which has proved to be very robust and well suited to the fermentation of lignocellulosic hydrolysates(14). For the expansion of ethanol industry, it is necessary the searching for more competitive ethanologenic microorganisms. As they have been studied, the bacterial specie Zymomonas mobilis has attracted the attention of researchers and showed as a promising ethanol producer $(15,16)$. Due to its high fermentation potential, Zymomonas mobilis have been the subject of numerous studies, which results in a production of ethanol comparable to or even greater than that obtained by yeasts $(17,18,19,20,21,22)$. The synthesis of ethanol is conventionally performed by yeast, but the bacterial Zymomonas sp. has a special ability for this production, with an attractive alternative to the current global demand for fuel. When compared with Saccharomyces cerevisiae, high specific productivity and high tolerance to ethanol and lower production of biomass is achieved.

These microorganisms uses tiny fraction of sugar as carbon source, approximately $98 \%$ destined for the fermentation and only $2 \%$ for growth. Like much of chemoorganotrophic organisms, the bacterial Z. mobilis need sources of nitrogen, phosphorus, sulfur, and micronutrients for the metabolism functioning and synthesis of the cells 
in a form assailable by the microorganism (23). They also require water, carbon, oxygen and growth factor (24), hence the great need for optimizing the optimal concentrations of nutrients for bacterial metabolism.

\section{Objective:-}

The aim of this work was to study the influence of the medium components (Yeast Extract, $\mathrm{KH}_{2} \mathrm{PO}_{4},\left[\mathrm{NH}_{4}\right]_{2} \mathrm{SO}_{4}$, $\mathrm{MgSO}_{4} .7 \mathrm{H}_{2} \mathrm{O}$ ) on the fermentation conditions for the ethanol production from sugarcane bagasse by $\mathrm{Z}$. mobilis using Simultaneous Saccharification and Fermentation technology.

Materials and Methods:-

Substrate: Costa Pinto Distillery (SP, Brazil) kindly provided the sugarcane bagasse (Saccharum spp.).

Pretreatment: The bagasse was primarily hydrolyzed, in order to disorganize the lignocellulosic material and remove the hemicellulose fraction. The following conditions for acid pretreatment were $1 \% \mathrm{of}_{2} \mathrm{SO}_{4}$, solid-liquid ratio of $1: 2(\mathrm{~g} / \mathrm{ml})$, temperature of $121^{\circ} \mathrm{C}$ for 30 minutes (25). The hemicellulose was removed, and the remaining solid residue (cellulignin) was partially delignified by an alkaline pretreatment with $4 \% \mathrm{NaOH}$, using solid-liquid ratio of $1: 20(\mathrm{~g} / \mathrm{ml})$, at $121^{\circ} \mathrm{C}$ for 30 minutes $(26)$. The cellulignin was washed with distilled water until the aqueous phase remained clear. Resulting solid material with increased cellulose accessibility was subjected to the enzymatic cellulose hydrolysis, which occurred using the commercial preparation Multifect (Genencor, USA) at a temperature of $50^{\circ} \mathrm{C}, 12$ hours, enzyme load of $25 \mathrm{FPU} / \mathrm{g}$ and solid: liquid ratio of $3: 10(\mathrm{~g} / \mathrm{ml})(27)$. The solid fraction is the cellulose and the liquid is the fermentation medium, containing other nutrients.

Microorganism and Inoculum Preparation: The Department of Antibiotics of the Federal University of Pernambuco, Brazil, kindly provided the Zymomonas mobilis CP4 used in this study. The strain was grown in a liquid medium $\left(20 \mathrm{~g} / \mathrm{L}\right.$ of glucose and $5 \mathrm{~g} / \mathrm{L}$ of yeast extract) recommended by Swing \& De Ley (16), at $30^{\circ} \mathrm{C}$ for 24 hours, and maintained at $4^{\circ} \mathrm{C}$. Monthly transferences were performed for maintenance of cell viability. The inoculum was grown in a medium composed of glucose, $20 \mathrm{~g} / \mathrm{L}$; yeast extract, $2.5 \mathrm{~g} / \mathrm{L}$; Ammonium Sulfate, $1 \mathrm{~g} / \mathrm{L}$; Potassium Phosphate, $1 \mathrm{~g} / \mathrm{L}$ and Magnesium Sulfate, $0.5 \mathrm{~g} / \mathrm{L}$. The cultures were shaken in a rotary shaker at 150 $\mathrm{rpm}$, at $30^{\circ} \mathrm{C}$ for 20 hours. After growth, the cells were centrifuged ( $8000 \mathrm{rpm}, 20$ minutes), and their concentration was determined by measuring the optical density of a diluted sample at $600 \mathrm{~nm}$ (SPECTRUMLAB 22 PC), using a standard curve of absorbance against dry cell mass. The centrifuged cells were inoculated in the enzymatically pretreated solids.

Fermentation Assays: The fermentation medium (enzymatically pretreated solids) was supplemented with the same nutrients used for the inoculum preparation medium, without glucose, providing the technical implementation of the SSF process. Batch fermentations experiments were performed in $500 \mathrm{~mL}$ Erlenmeyer flasks with a working volume of $100 \mathrm{~mL}$ to define the optimum process conditions. Additionally, fermentations were carried out in a $1.5 \mathrm{~L}-$ bioreactor (BIOFLO III, New Brunswick Scientific, USA) with control of temperature, $\mathrm{pH}$ and agitation. The reactor operated with a working volume of $500 \mathrm{~mL}$ and the temperature and $\mathrm{pH}$ were set at $30^{\circ} \mathrm{C}$ and 5.0 , respectively. The $\mathrm{pH}$ was monitored using a sterile $\mathrm{pH}$ electrode and controlled by adding $1 \mathrm{M} \mathrm{KOH}$. The kinetics of SSF in bioreactor was evaluated in the optimum conditions established in the shake flask experiments.

Analytical methods: Cell quantification was determined as described previously. Samples were analyzed for glucose, cellobiose and ethanol concentrations by high-efficiency liquid chromatography (HPLC) using the chromatographic system (WATERS) consisting of a HPX-87P (Bio-Rad) column, WATERS 510 pump, a refractive index detector WATERS 410 and Empower software ${ }^{\mathrm{TM}}$ integrator. The standard solution consists of cellobiose, glucose and ethanol concentrations of $5 \mathrm{~g} / \mathrm{L}, 10 \mathrm{~g} / \mathrm{L}$ and $15 \mathrm{~g} / \mathrm{L}$, respectively. The end of fermentation was determined through the stabilization of the production of ethanol, as verified by the reading of two consecutive and equal values of ethanol content.

Optimization of ethanol concentration: Response surface methodology (RSM) is the one suitable for identifying the effect of individual variables and for seeking the optimum conditions for a multivariable system efficiently (28). The statistical analysis of the data was performed using "Design Expert" software (7.1.6., Stat-Ease). As seen in Table 1, a complete factorial design $2^{4}$ was done, where the parameters analyzed were concentrations of yeast extract $(\mathrm{g} / \mathrm{L}), \mathrm{KH}_{2} \mathrm{PO}_{4}(\mathrm{~g} / \mathrm{L}),\left(\mathrm{NH}_{4}\right)_{2} \mathrm{SO}_{4}(\mathrm{~g} / \mathrm{L})$ and $\mathrm{MgSO}_{4} \cdot 7 \mathrm{H}_{2} \mathrm{O}(\mathrm{g} / \mathrm{L})$ added to cellulignin in the beginning of hydrolysis, which along with glucose generated, provided the technical implementation of SSF. 
Table 1:- Independent variables in the experimental design.

\begin{tabular}{|c|c|c|c|c|c|c|}
\hline \multirow{2}{*}{\multicolumn{2}{|c|}{ PARAMETERS }} & \multicolumn{5}{|c|}{ Real Levels } \\
\hline & & $-\alpha$ & - & $\mathbf{0}$ & + & $+\alpha$ \\
\hline $\mathbf{A}$ & Yeast Extract (g/L) & 0 & 5 & 12.5 & 20 & 27 \\
\hline $\mathbf{B}$ & $\mathrm{KH}_{2} \mathrm{PO}_{4}(\mathrm{~g} / \mathrm{L})$ & 0 & 1 & 2.5 & 4 & 5.5 \\
\hline $\mathbf{C}$ & $\left(\mathrm{NH}_{4}\right)_{2} \mathrm{SO}_{4}(\mathrm{~g} / \mathrm{L})$ & 0 & 0.5 & 1.25 & 2 & 2.75 \\
\hline D & $\mathrm{MgS0}_{4} \cdot 7 \mathrm{H}_{2} \mathrm{O}(\mathrm{g} / \mathrm{L})$ & 0 & 0.5 & 1.25 & 2 & 2.75 \\
\hline
\end{tabular}

\section{Results andDiscussion:-}

This session will present the experiments concerning the use of the experimental design, evaluating the influence of medium components (yeast extract, $\mathrm{KH}_{2} \mathrm{PO}_{4},\left(\mathrm{NH}_{4}\right)_{2} \mathrm{SO}_{4}$ and $\mathrm{MgSO}_{4} .7 \mathrm{H}_{2} \mathrm{O}$ on the Simultaneous Saccharification and Fermentation technology. The complete $2^{4}$ factorial design generated 30 runs (24 independent runs and 6 repetitions of central point), shown in Table 2.

Table 2:- $2^{4}$ Central composite design investigating effects of adding yeast extract $(\mathrm{g} / \mathrm{L}), \mathrm{KH}_{2} \mathrm{PO}_{4}(\mathrm{~g} / \mathrm{L}),\left(\mathrm{NH}_{4}\right)_{2} \mathrm{SO}_{4}$ $(\mathrm{g} / \mathrm{L})$ and $\mathrm{MgSO}_{4} \cdot 7 \mathrm{H}_{2} \mathrm{O}(\mathrm{g} / \mathrm{L})$ in the ethanol production.

\begin{tabular}{|c|c|c|c|c|}
\hline $\begin{array}{l}\text { Yeast Extract } \\
(\mathrm{g} / \mathrm{L})\end{array}$ & $\begin{array}{l}\mathrm{KH}_{2} \mathrm{PO}_{4} \\
(\mathrm{~g} / \mathrm{L})\end{array}$ & $\begin{array}{l}\left(\mathrm{NH}_{4}\right)_{2} \mathrm{SO4} \\
(\mathrm{g} / \mathrm{L})\end{array}$ & $\begin{array}{l}\mathbf{M g S 0}_{4.7} \cdot \mathrm{H}_{2} \mathrm{O} \\
(\mathrm{g} / \mathrm{L})\end{array}$ & $\begin{array}{l}\text { Ethanol } \\
(\mathrm{g} / \mathrm{L})\end{array}$ \\
\hline 5 & 1 & 0.5 & 0.5 & 54 \\
\hline 20 & 1 & 0.5 & 0.5 & 62 \\
\hline 5 & 4 & 0.5 & 0.5 & 45 \\
\hline \begin{tabular}{|l|}
20 \\
\end{tabular} & 4 & 0.5 & 0.5 & 59 \\
\hline 5 & 1 & 2 & 0.5 & 38 \\
\hline 20 & 1 & 2 & 0.5 & 60 \\
\hline 5 & 4 & 2 & 0.5 & 34 \\
\hline 20 & 4 & 2 & 0.5 & 52 \\
\hline 5 & 1 & 0.5 & 2 & 32 \\
\hline \begin{tabular}{|l|}
20 \\
\end{tabular} & 1 & 0.5 & 2 & 57 \\
\hline 5 & 4 & 0.5 & 2 & 33 \\
\hline 20 & 4 & 0.5 & 2 & 56 \\
\hline 5 & 1 & 2 & 2 & 28 \\
\hline 20 & 1 & 2 & 2 & 54 \\
\hline 5 & 4 & 2 & 2 & 48 \\
\hline 20 & 4 & 2 & 2 & 63 \\
\hline 0 & 2.5 & 1.25 & 1.25 & 30 \\
\hline 27.5 & 2.5 & 1.25 & 1.25 & 65 \\
\hline \begin{tabular}{|l}
12.5 \\
\end{tabular} & 0 & 1.25 & 1.25 & 33 \\
\hline \begin{tabular}{|l}
12.5 \\
\end{tabular} & 5.5 & 1.25 & 1.25 & 38 \\
\hline 12.5 & 2.5 & O & 1.25 & 34 \\
\hline 12.5 & 2.5 & 2.75 & 1.25 & 37 \\
\hline \begin{tabular}{|l}
12.5 \\
\end{tabular} & 2.5 & 1.25 & 0 & 34 \\
\hline 12.5 & 2.5 & 1.25 & 2.75 & 62 \\
\hline \begin{tabular}{|l}
12.5 \\
\end{tabular} & 2.5 & 1.25 & 1.25 & 65 \\
\hline \begin{tabular}{|l}
12.5 \\
\end{tabular} & 2.5 & 1.25 & 1.25 & 63 \\
\hline 12.5 & 2.5 & 1.25 & 1.25 & 62 \\
\hline 12.5 & 2.5 & 1.25 & 1.25 & 61 \\
\hline \begin{tabular}{|l|}
12.5 \\
\end{tabular} & 2.5 & 1.25 & 1.25 & 62 \\
\hline 12.5 & 2.5 & 1.25 & 1.25 & 60 \\
\hline
\end{tabular}

The highest ethanol concentration obtained was $65 \mathrm{~g} / \mathrm{L}$, when $12.5 \mathrm{~g} / \mathrm{L}$ yeast extract, $2.5 \mathrm{~g} / \mathrm{L} \mathrm{KH} \mathrm{KH}_{2} \mathrm{PO}_{4} 1.25 \mathrm{~g} / \mathrm{L}$ $\left(\mathrm{NH}_{4}\right)_{2} \mathrm{SO}_{4}$ and $0.5 \mathrm{~g} / \mathrm{L} \mathrm{MgSO}_{4} \cdot 7 \mathrm{H}_{2} \mathrm{O}$ were used.The presence of yeast extract, rich in nitrogen, significantly increases the production of ethanol, as indicated by the comparison of runs 9 and 10. These experiments have the same concentrations of other nutrients and when yeast extract was added, ethanol production increased from $33 \mathrm{~g} / \mathrm{L}$ to $57 \mathrm{~g} / \mathrm{L}$. However, the presence of high concentrations of this nutrient causes a decrease in ethanol production due 
to an excess of nitrogen source (29). Soleimani et al. (2012) also found that ethanol production was reduced after removal of nutrients from the culture medium, such as yeast extract and peptone (30). However, some studies have shown that the use of some agro-industrial waste can substitute carbon or nitrogen sources, as observed by Patle\&Lal (2008) (31).

In the other hand, Neto et al. (2005) found that large concentrations of yeast extract may cause a decrease in ethanol production due to an excess of nitrogen source. Thus, there is an increase in the biomass concentration, since Zymomonas sp. uses this compound not only as a source of nitrogen, but also as blocks for biosynthesis, implying a lower energy requirement. This fact would justify the decrease in the production of ethanol and, consequently, the lower ATP synthesis. The regulation of nitrogen is of fundamental importance in industrial microbiology, since it affects the enzymes meabolization from primary and secondary metabolism. Thus, many secondary metabolic pathways are negatively affected by growth-enhancing nitrogen sources, such as ammonium salts, as well as high concentrations of nitrogen can affect the synthesis of these enzymes (Belä̈ch\&Senez, 1965; Neto et al., 2005) $(32,29)$.

Thus, there is an increase in biomass concentration as Zymomonas sp. uses this compound not only as a nitrogen source but also as building blocks for biosynthesis, resulting in a reduced need for energy, which would justify a reduction in ethanol production and, consequently, less formation of ATP. The synthesis of enzymes using other nitrogen sources is repressed until the primary substrate is completely depleted.

In experiments 17, 19, 21 and 23, without addition of yeast extract $(\mathrm{g} / \mathrm{L}), \mathrm{KH}_{2} \mathrm{PO}_{4}(\mathrm{~g} / \mathrm{L}),\left(\mathrm{NH}_{4}\right)_{2} \mathrm{SO}_{4}(\mathrm{~g} / \mathrm{L})$ and $\mathrm{MgSO}_{4} .7 \mathrm{H}_{2} \mathrm{O}(\mathrm{g} / \mathrm{L})$, respectively, ethanol is still produced, due the presence of $44.6 \%$ carbon, $5.8 \%$ hydrogen, $44.5 \%$ oxygen, $0.6 \%$ nitrogen, $0.1 \%$ sulfur and $4.4 \%$ other elements in sugarcane bagasse $(24,33)$. Nonetheless, there is still need for the presence of nutrients that contain chemical elements such as magnesium and phosphorus.

Cao et al. (34) have reported that $\mathrm{KH}_{2} \mathrm{PO}_{4},\left(\mathrm{NH}_{4}\right)_{2} \mathrm{SO}_{4}$, and $\mathrm{MgSO}_{4}$ would influence the growth and metabolism of the yeast cells. Phosphorus is present in $\mathrm{KH}_{2} \mathrm{PO}_{4}$, witch has an important role in metabolic pathways that are initiated with substrate phosphorylation. It is also a constituent of ATP molecules that are present in the energy mechanism of the cells. Methionine, cysteine and sulfates can supply Sulfur, present in $\left(\mathrm{NH}_{4}\right)_{2} \mathrm{SO}_{4}$ structural constituent of the cell and of great importance for the formation of proteins (35). $\mathrm{MgSO}_{4}$ is the best sulfur source, and serves as a source of magnesium, which is responsible for the structural stability of several enzymes, but also for preventing the formation of vesicles on the outer membrane of the cell (36).

The presence of these nutrients in their highest levels associated with increased extract concentration, promotes increased ethanol production, as shown in the experimental 16. Therefore, there is a high production of ethanol when the concentration of $\mathrm{KH}_{2} \mathrm{PO}_{4}(\mathrm{~g} / \mathrm{L})$ increases in relation to increasing $\mathrm{MgSO}_{4} .7 \mathrm{H}_{2} \mathrm{O}(\mathrm{g} / \mathrm{L})$ and a smaller increase through its association with $\left(\mathrm{NH}_{4}\right)_{2} \mathrm{SO}_{4}(\mathrm{~g} / \mathrm{L})$, besides there is a decline of ethanol when the nutrients are associated at high concentrations. The increase in nutrients should occur simultaneously, as shown when experiment 1 , which resulted in $54 \mathrm{~g} / \mathrm{L}$ of ethanol is compared to experiment 15 where there was an increase in nutrients, except yeast extract, thus decreasing the ethanol production to $48 \mathrm{~g} / \mathrm{L}$. Therefore, a synergistic effect between the parameters analyzed is necessary.

Statistical analysis: The Statistical analysis of variance obtained by the factorial design indicated in Table 3, shows that the model was very significant, with $(p<0.05)$, as well as the coefficient of total determination $\left(\mathrm{R}^{2}\right)$ observed for the response to ethanol production in $\mathrm{g} / \mathrm{L}$, was 0.995 , suggesting a good model fitting to experimental data. Moreover, the residue was low and not significant $(p>0.05)$, which did not invalidate the model for predictive purposes, because the equation had a high $\mathrm{R}^{2}$. The resulting ethanol concentration model is in equation $(\mathbf{1})$.

$[$ Ethanol] $=+52.17+131.29 * A+3.05 * B+2.50 * C+6.59 * D-1.00 * A * B+0.38 * A * C+2.00 * A * D+1.50 * B * C+3.63 *$

$B * D+3.50 * C * D+8.65 * A 2-5.07 * B 2-5.04 * C 2-2.59 * D 2-0.88 * A * B * C-1.25 * A * B * D-1.88 *$

$A * C * D+1.50 * B * C * D-2.43 * A 2 * B-3.50 * A 2 * C-8.96 * A 2 * D-85.12 * A * B 2-36.42 * A 3$

(1) 
Table 3:-Analysis of variance in the ethanol production [Partial sum of squares]. $\mathrm{SS}=$ Sum of Squares; DF=Degree of Freedom; MS=Medium Square.

\begin{tabular}{|l|l|l|l|l|l|}
\hline Source & SS & DF & Ms & F value & $p>$ F \\
\hline Model & $\mathbf{4 6 9 3 . 8 4}$ & $\mathbf{1 2}$ & $\mathbf{3 9 1 . 1 5}$ & $\mathbf{7 8 . 3 1}$ & $<\mathbf{0 . 0 0 0 1}$ \\
\hline Residual & $\mathbf{7 4 , 8 9 5 8 3}$ & $\mathbf{6}$ & $\mathbf{1 2 , 4 8 2 6 4}$ & & \\
\hline Lack of fit & $\mathbf{6 0 , 0 6 2 5}$ & $\mathbf{1}$ & $\mathbf{6 0 , 0 6 2 5}$ & $\mathbf{2 0 , 2 4 5 7 9}$ & $\mathbf{0 . 0 0 6 4}$ \\
\hline Pure error & $\mathbf{1 4 , 8 3 3 3 3}$ & $\mathbf{5}$ & $\mathbf{2 , 9 6 6 6 6 7}$ & & \\
\hline Cor. total & $\mathbf{4 5 0 5 , 3 6 7}$ & $\mathbf{2 9}$ & $\mathbf{4 5 0 5 , 3 6 7}$ & $\mathbf{2 9}$ & $\mathbf{4 5 0 5 , 3 6 7}$ \\
\hline
\end{tabular}

The variable A (yeast extract) presents the highest influence, followed by $\mathrm{D}\left(\mathrm{MgSO}_{4} \cdot 7 \mathrm{H}_{2} \mathrm{O}\right)$, which in turn is higher than $\mathrm{B}\left(\mathrm{KH}_{2} \mathrm{PO}_{4}\right)$ and finally $\mathrm{C}\left(\left[\mathrm{NH}_{4}\right]_{2} \mathrm{SO}_{4}\right)$, which has low values of Sum of Squares. The interaction of these four variables also resulted in high values of Fisher, indicating a great synergism between nutrients in the fermentation by $Z$. mobilis, providing increased amounts of ethanol. The interactions between nutrients complementary pairs had to be quite significant. The most influential was between $\mathrm{BD}\left(\mathrm{KH}_{2} \mathrm{PO}_{4}\right.$ and $\left.\mathrm{MgSO}_{4} \cdot 7 \mathrm{H}_{2} \mathrm{O}\right), \mathrm{BC}\left(\mathrm{KH}_{2} \mathrm{PO}\right.$ and $\left.\left[\mathrm{NH}_{4}\right]_{2} \mathrm{SO}_{4}\right)$, followed by $\mathrm{CD}\left(\left[\mathrm{NH}_{4}\right]_{2} \mathrm{SO}_{4}\right.$ and $\left.\mathrm{MgSO}_{4} .7 \mathrm{H}_{2} \mathrm{O}\right)$, as shown in Figure 1.

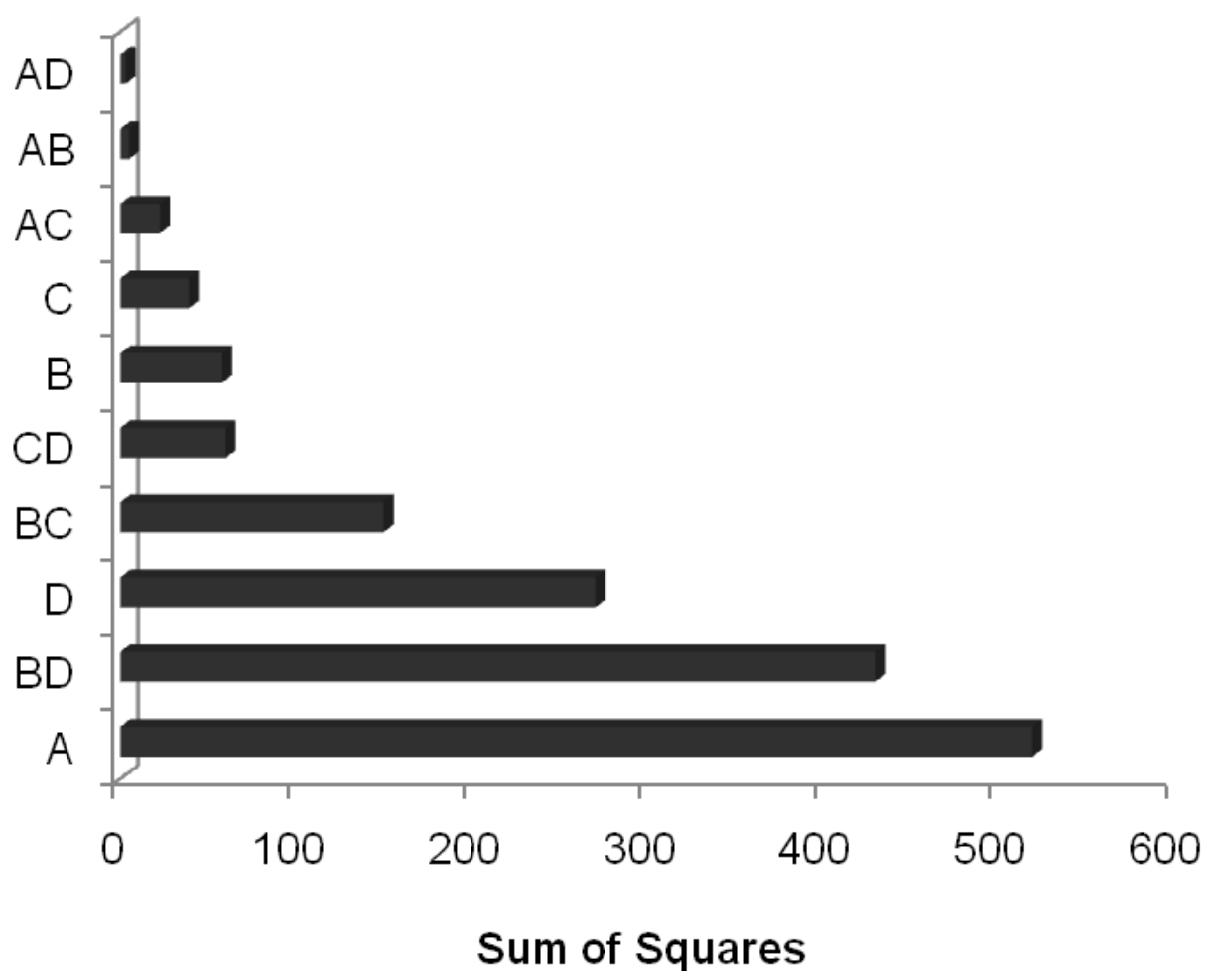

Figure 1:- Histogram of variables influence, according to the Sum of Squares.

The double interactions between nutrients analyzed for ethanol production display the interaction between $\mathrm{KH}_{2} \mathrm{PO}_{4}$ $(\mathrm{g} / \mathrm{L})$ and Yeast extract $(\mathrm{g} / \mathrm{L})$ are very low and there is no intersection between the two variables. This, in turn possesses high interactions with the variables represented by $\left(\mathrm{NH}_{4}\right)_{2} \mathrm{SO}_{4}(\mathrm{~g} / \mathrm{L})$ and $\mathrm{MgSO}_{4} \cdot 7 \mathrm{H}_{2} \mathrm{O}(\mathrm{g} / \mathrm{L})$.

Figures 2 show the 3-D response surface plots demonstrate interaction between the parameters A, B, C and D, which represent yeast extract $(\mathrm{g} / \mathrm{L}), \mathrm{KH}_{2} \mathrm{PO}_{4}(\mathrm{~g} / \mathrm{L}),\left(\mathrm{NH}_{4}\right)_{2} \mathrm{SO}_{4}(\mathrm{~g} / \mathrm{L})$ and $\mathrm{MgSO}_{4} \cdot 7 \mathrm{H}_{2} \mathrm{O}(\mathrm{g} / \mathrm{L})$, respectively. Note that in Figure $2 \mathrm{~A}$ in connection with $\mathrm{MgSO} 4$ and $\left(\mathrm{NH}_{4}\right)_{2} \mathrm{SO}_{4}$ with $\mathrm{KH}_{2} \mathrm{PO}_{4}$ and yeast extract in their central points, ethanol production is at its optimal level when the variable $\mathrm{D}$ is at its center point to the higher level and the variable $\mathrm{C}$ is at the central point, respectively. 


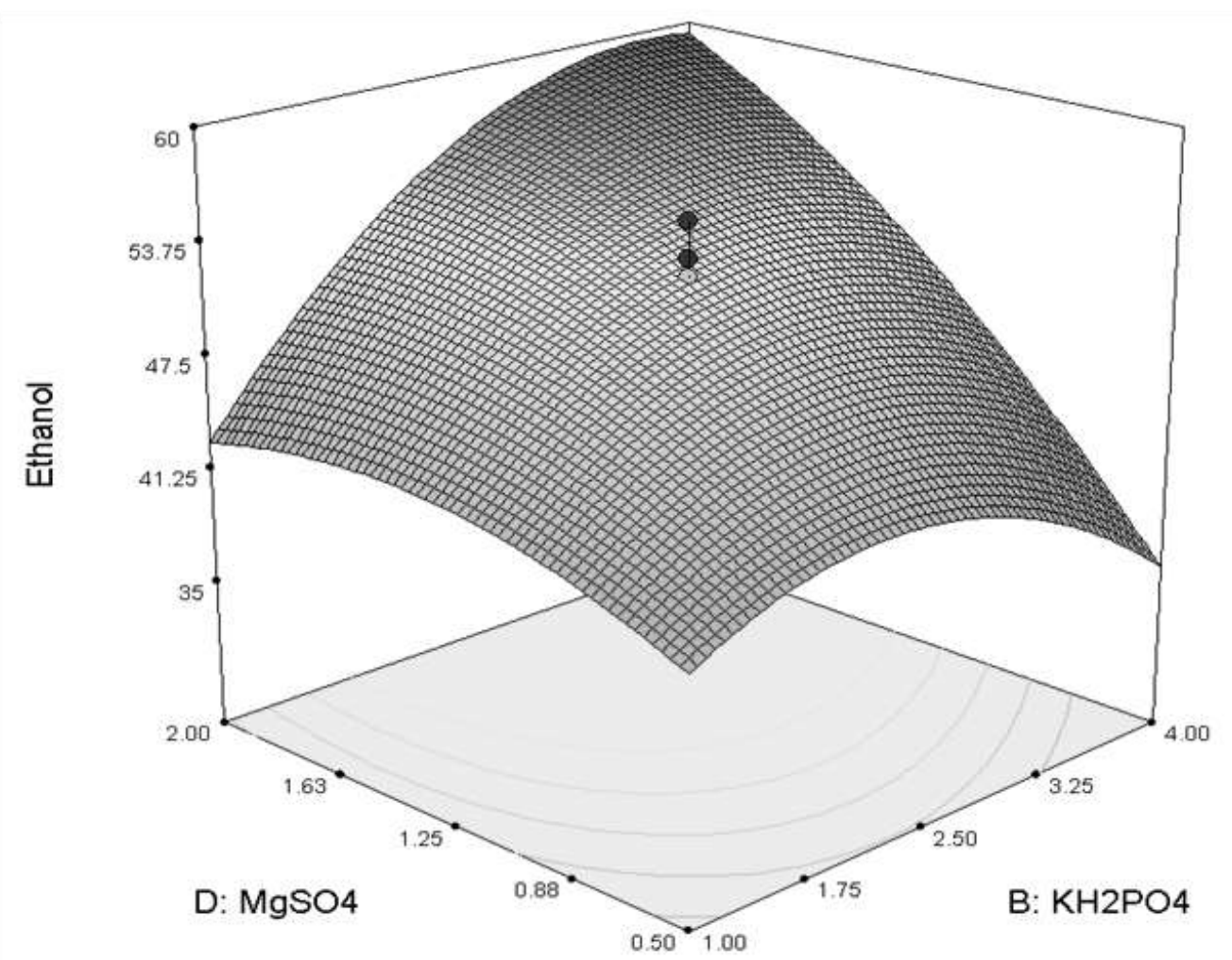

Figure 2 (A):- Response surface plot showing the effect of yeast extract $(\mathrm{g} / \mathrm{L}), \mathrm{KH}_{2} \mathrm{PO}_{4}(\mathrm{~g} / \mathrm{L})$, and their combined effects on ethanol concentration.

Figure 2B shows that ethanol production is at its optimal level when the variables C and D, respectively, are from their central points to their highest levels. Underscoring the results presented in the experiments, which exhibits the highest production of ethanol in the central points of the parameters, although the same values were obtained at higher levels indicating that even with increased concentrations of nutrients, with the same concentrations of enzymes, solid and cells, the concentration of ethanol is stagnant, starting inhibition by large amounts of nutrients, affecting the osmolarity of the cell or the growth of bacteria exacerbated by shifting the focus of the metabolism of ethanol production to the growth of bacteria. 


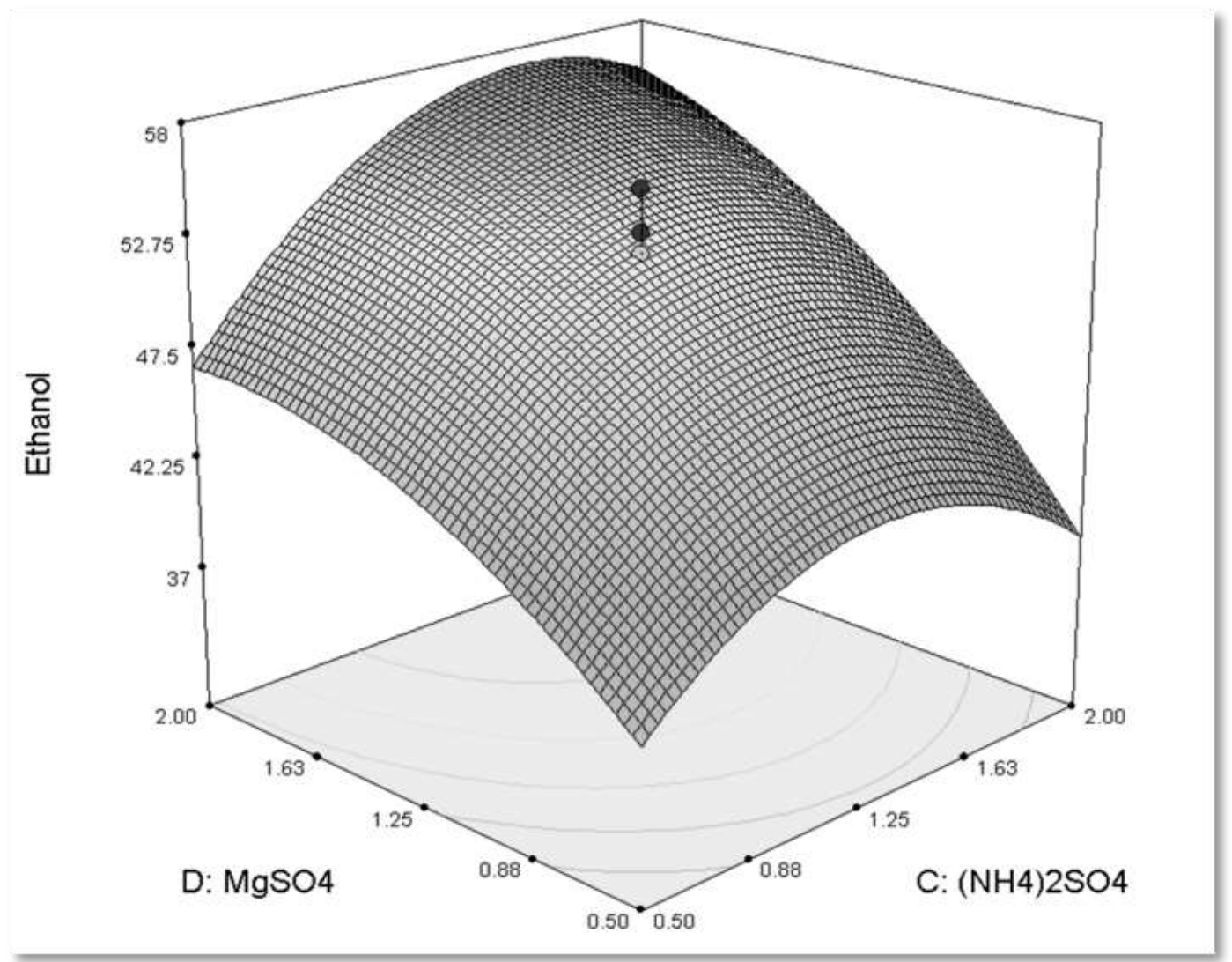

Figure 2 (B):- Response surface plot showing the effect of $\mathrm{MgSO}_{4} \cdot 7 \mathrm{H}_{2} \mathrm{O}(\mathrm{g} / \mathrm{L}),\left(\mathrm{NH}_{4}\right)_{2} \mathrm{SO}_{4}$ and their combined effects on ethanol concentration.

The volumetric productivity and production of ethanol depends, among several factors, according to the substrate used, additional nutrients, as well as the microorganism to be used. Pinillaet al. (2011) obtained high concentrations of ethanol $(83.81 \mathrm{~g} / \mathrm{L})$, from glucose added of yeast extract, peptone and salts, after isolation of colonies grown on sugarcane molasses (37). In the present study, the use of sugarcane, fructose, glucose, sucrose and galactose mixtures was achieved by Wiikins (2009), reaching $43.5 \mathrm{~g} / \mathrm{L}$ ethanol at the end of the fermentation process (38), whereas Maitiet al. (2011) reached $58.4 \mathrm{~g} / \mathrm{L}$ from sugarcane molasses (39).

These results are similar to observable by $Y u$ et al. (28), which optimized the nutrient concentrations in synthetic medium and noted a significant effect of yeast extract on biomass, associated to the carbon source. They observed an increase in Ammonium Sulfate concentration that resulted in an increase in ethanol yield, but above an optimum level the ethanol yield decreased. No significant variation was observed with the phosphate and nitrogen source, resulting in an insignificant role for the Potassium Phosphate and for the Ammonium Sulphate, as the cells can utilize nitrogen available from yeast extract (36).. Excess nitrogen could lead to more biomass but less ethanol production, as shown in this work.

The experimental validation in bioreactor yielded a SSF initial glucose concentration of $85 \mathrm{~g} / \mathrm{L}$, final ethanol concentration of $65 \mathrm{~g} / \mathrm{L}$ and volumetric productivity of $2.70 \mathrm{~g} . \mathrm{L}^{-1} \cdot \mathrm{h}^{-1}$, with a fermentation time of approximately 24 hours, at temperature of $30^{\circ} \mathrm{C}$, orbital agitation at 150rpm and $\mathrm{pH} 5$ (Figure 3). 


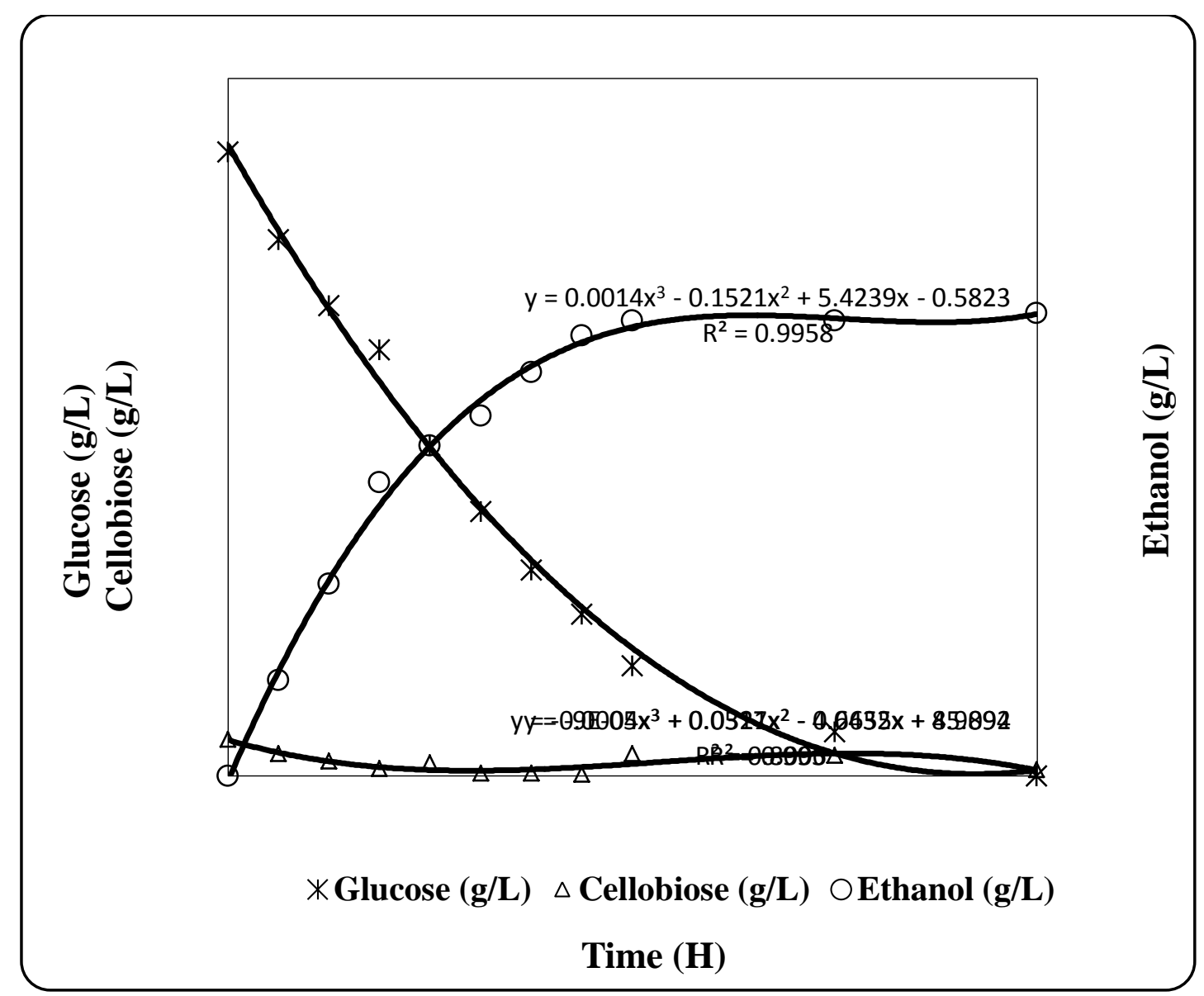

Figure 3:- Validation of the experimental design optimum conditions $\left(\mathrm{S}: \mathrm{L}=1: 3 ; \mathrm{EL}=25 \mathrm{FPU} / \mathrm{g} ; \mathrm{X}_{\mathrm{o}}=4 \mathrm{~g} / \mathrm{L}\right.$ ) for the SSF process in bioreactor with Zymomonasmobilis CP4.

\section{Conclusions:-}

The experiments showed that it is possible to optimize ethanol production by examining the addition of nutrients in the fermentation medium, through the experimental designs of response surfaces. All the nutrients proved to be significant and essential to the metabolism of bacteria. The increase of yeast extract was mainly responsible for the increase of ethanol concentration, followed by $\mathrm{KH}_{2} \mathrm{PO}_{4}, \mathrm{MgSO}_{4} \cdot 7 \mathrm{H}_{2} \mathrm{O}$ and $\left(\mathrm{NH}_{4}\right)_{2} \mathrm{SO}_{4}$, that were less significant as independent variables, but showed high levels of sum of squares, when they were involved in all the interactions studied.

The optimal conditions found were yeast extract $(12.5 \mathrm{~g} / \mathrm{L}), \mathrm{KH}_{2} \mathrm{PO}_{4}(2.5 \mathrm{~g} / \mathrm{L}),\left(\mathrm{NH}_{4}\right)_{2} \mathrm{SO}_{4}(1.25 \mathrm{~g} / \mathrm{L})$ and $\mathrm{MgSO}_{4}$ $(1.25 \mathrm{~g} / \mathrm{L})$. It resulted in the maximum ethanol concentration of $65 \mathrm{~g} / \mathrm{L}$, with $85 \mathrm{~g} / \mathrm{L}$ of SSF initial glucose concentration, reaching the highest volumetric productivity of $2.63 \mathrm{~g} / \mathrm{L} . \mathrm{h}$, at temperature $30^{\circ} \mathrm{C}$, orbital agitation at $150 \mathrm{rpm}, \mathrm{pH} 5$ in bioreactor.

It was verified, therefore, that cellulose constitutes an excellent source of carbohydrates for the execution of the process of simultaneous enzymatic hydrolysis and fermentation by Zymomonasmobilis, which presented promising for the production of this biofuel, due to its high capacity of glucose absorption, High specific rates of ethanol production, resulting in high productivity values. The results obtained with the present work were satisfactory, however, it is necessary to continue with the elaboration of new strategies so that the inhibitory and unsatisfactory issues placed throughout the text are circumvented, as well as the development of molecular biology techniques for the Evidence of genetic transformation, generating opportunities for future and interesting technological developments. 


\section{Acknowledgments:-}

The authors are grateful to the Brazilian Council for Research (CNPq); the Rio de Janeiro Foundation for Science and Technology (FAPERJ) and the Brazilian Oil Company (PETROBRAS) for scholarship and other financial supports.

\section{References:-}

1. Naik, S.N.; Goud, V.V.; Rout, P. K.; Dalai, A. K. Production of first and second generation biofuels: A comprehensive review. http://dx.doi.org/10.1016/j.rser.2009.10.003

2. Balat, M. (2011) Production of bioethanol from lignocellulosic materials via the biochemical pathway: A review. Energy Conversion and Management 52: 858-875.

3. Sarris, D.;Papanikoalaou, S. Biotechnological Production of ethanol: Biochemistry, PROCESSES AND TECHNOLOGIES. ENG. LIFE SCI. 2016, 16, 307-329.

4. Knauf M. \& Moniruzzaman, M. (2004) Lignocellulosic Biomass Processing: A Perspective. International Sugar Journal 106: 12-23.

5. Demirbas A.; Karslioglu S. (2007) Biodiesel production facilities from vegetable oils and animal fats. Energy Source 29:133-41.

6. Lang X.; Macdonald D.G.; Hill G.A. (2001) Recycle bioreactor for bioethanol production from wheat starch II. Fermentation and economics. Energy Source 23:427-36.

7. Lennartsson, P. R.; Erlandsson, P.; Taherzadeh, M. J. Integration of the first and second generation bioethanol processes and the importance of by-products. Bioresource Technology 165 (2014) 3-8.

8. Hartemink, A.E. (2008) Sugarcane for bioethanol: soil and environmental issues, AdvAgron99: 125-182.

9. CONAMA (2015) Cana-de-açúcar: acompanhamento da safrabrasileira, V.2- SAFRA, 2015/16- N.3 Terceirolevantamento.

10. Trostle, R. Global agricultural supply and demand: factors contributing to the recent increase in food commodity prices. USDA economic research service, report WRS-0801, Washington, DC; July 2008.

11. Pereira Jr., N. (2008) Biomass of lignocellulosic composition for fuel ethanol production within the context of biorefinery. Escola de Química/UFRJ.

12. McMillan, J.D.; Newman, M.M.; Templeton, D.W.; Mohagheghi, A. (1999) Simultaneous saccharification and cofermentation of dilute-acid pretreated yellow poplar hardwood to ethanol using xylose-fermenting Zymomonasmobilis. Appl. Biochem. Biotech.77-79: 649-665.

13. Galbe, M.; Zacchi G. (2002) A review of the production of ethanol from softwood, ApplMicrobiolBiotechnol59: 618-628.

14. Tano, M.; Buzato, J.; Celliogoi, M. A. (2000) Sugar Cane Juice Fermentation by Zymomonas mobilis CP4 Subjected to Inhibition by Ethanol and High Initial Concentration of Substrate. Brasilian Arch. Biol. Tech. 43.

15. Daugulis, A. J.; McLellan, P. J.; Li, J. (1997) Experimental investigation and modeling of oscillatory behavior in the continuous culture of Zymomonasmobilis. Biotech. andBioeng. 99-105.

16. Swings, J. and DeLey, J. (1977) The Biology of Zymomonas. Bacteriological Reviews41:1-46.

17. M. X. He, B. Wu, H. Qin, Z. Y. Ruan, F. R. Tan, J. L. Wang, Z. X. Shui, L. C. Dai, Q. L. Zhu, K. Pan, X. Y. Tang, W. G. Wang and Q. C. Hu, Biotechnol. Biofuels, 2014, 7, 101.

18. P. S. Panesar, S. S. Marwaha and J. F. Kennedy, J. Chem. Technol. Biotechnol., 2006, 81, 623-635.

19. Kannan, T. R.; Sangiliyandi, G.; Gunasekaran, P. (1998) Improved ethanol production from sucrose by a mutant of Zymomonasmobilis lacking sucrases in immobilized cell fermentation. Enzyme and Microbial Technology 22: $179-184$.

20. Gunasekaran, P. \&Chandrara, J. K. (1999) Ethanol fermentation technology - Zymomonasmobilis. Current Science 77: 56-68.

21. Yanase, H.; Iwata, M.; Nakahigashi, R.; Kita, K.; Kato, N.; Tonomura, K. (1992) Purification, crystallization, and characterization of the extracellular levansucrase from Zymomonasmobilis. Bioscience, Biotechnology and Biochemistry 56: 1335-1337.

22. Doelle, H. W., Kirk, L., Crittenden, R., Toh, H. and Doelle, M. (1993) Zymomonasmobilis - science and industrial application. Crit. Rev. Biotechnol. 13 (57-98).

23. You et al., (2017) Bio-ethanol production by Zymomonasmobilis using pretreated dairy manure as a carbon and nitrogen source. RSC Adv.,2017,7,3768.

24. Falcão de Morais, J. (1982) Zymomonasmobilise seuempregocomoagente de fermentaçãoalcoólica.Revista do Instituto de Antibióticos 1/2: 169-182.

25. Betancur, G. V. (2005). MSc thesis, Federal University of Rio de Janeiro, Rio de Janeiro, RJ. 
26. Vasques, M. P. (2007). DSc thesis, Federal University of Rio de Janeiro, Rio de Janeiro, RJ.

27. Santos, D. S.; Camelo, A. C.; Rodrigues, K. C. P.; Carlos, L. C.; Pereira Jr., N. (2009) Ethanol production from Sugarcane bagasse by Zymomonasmobilis using Simultaneous Saccharification and Fermentation (SSF) Process. Applied Biochemistry and Biotechnology121 (1-8): 93-105.

28. Yu, J.; Zhang, X.; Tan, T. (2009) Optimization of media conditions for the production of ethanol from sweet sorghum juice by immobilized Saccharomyces cerevisiae. Biomass and Bioenergy 33: 521-526.

29. Neto, D. C.; Buzato, J. B.; Pedrine, M. A.; Celligoi, C.; Oliveira, M. R. (2005) Otimização da produção de etanolporZymomonasmobilisnafermentação do melaço de cana-de-açúcar. CiênciasExatas e Tecnológicas26 (1): 17-22.

30. Soleimani, S., Ghasemi, M.F. and Shokri, S, "Ethanol production by Zymomonasmobilis PTCC 1718 using low cost substrates," African Journal of Microbiology Research, 6 (4). 704-712. Jan.2012.

31. Patle S, Lal B. Investigation of the potential of agro-industrial material as low cost substrate for ethanol production by using Candida tropicalis and Zymomonasmobilis. Biomass Bioenergy. 2008;32:596-602.

32. Belauich JP, Senez JC. Influence of aeration and of pantothenate on growth yields of Zymomonasmobilis. J Bacteriol. 1965 May;89:1195-200.

33. Simões, M. S.; Rocha, J. V.; Lamparelli, R. A. C. (2005) Indicadores de crescimento e produtividade da canade-açúcar. Scientiaagricola62 (1): 23-30.

34. Cao, J. F.; Gao, B. P.; Gu, W. B. (2006) Study on producing alcohol fermentation conditions by sweet sorghum juice. ActaAgriculturaeBorealiOccidentaisSinica 15 (3): 201-3.

35. França, F. P. \& Rodrigues, C. S. (1985) FermentaçãoalcoólicadesenvolvidaporZymomonasMobilis CP-3. Revistalatino-americana de microbiologia. Revistalatino-americana de microbiologia 27: 27-30.

36. Galani, I.; Drainas, C.; Typas, M.A. (1985) Growth Requirements and the Establishment of a Chemically Defined Minimal Médium in Zymomonasmobilis. Biotechnology Letters Biotechnology Letters7: 673-678.

37. Pinilla, L. I; Sáez, R.G.T.; Ortiz, C. Bioethanol production in batch mode by a native strain of Zymomonas. World J MicrobiolBiotechnol (2011) 27:2521-2528. DOI 10.1007/s11274-011-0721-7

38. Wilkins, M. R. Effect of orange peel oil on ethanol production by Zymomonasmobilis. (2009) DOI: 10.1016/j.biombioe.2008.08.010.

39. B Maiti et al. Optimization of Process Parameters for Ethanol Production From Sugar Cane Molasses by ZymomonasMobilis Using Response Surface Methodology and Genetic Algorithm. ApplMicrobiolBiotechnol 90 (1), 385-395. 2011. 